\title{
Original
}

\section{Comparison of Etched Surface of Enamel with Nd: YAG Laser and Phosphoric Acid}

\author{
Silvio I. MYAKI*, José C. P. IMPARATO*, Wilson T. OLIVEIRA Jr. *, \\ Carlos P. EDUARDO** and li-Sei WATANABE*** \\ ${ }^{*}$ Pos-Graduate Student, School of Dentistry, University of São Paulo, Brazil \\ **Associate Professor, Department of Dentistry, University of São Paulo, Brazil \\ ${ }^{* * *}$ Full Professor of Anatomy, Department of Anatomy, Institute of Biomedical Sciences, \\ University of São Paulo, Brazil
}

(Accepted for Publication: January 31, 1994)

\begin{abstract}
The etching pattern for the enamel surface of human teeth was compared using $35 \%$ phosphoric acid and the use of the Nd: YAG laser with potency varying from $0.75 \mathrm{w}$ to $1.00 \mathrm{w}$, and $15 \mathrm{pps}$ during 90 seconds. The formation of tags was also observed in two groups, one treated with $35 \%$ phosphoric acid and the other with Nd: YAG laser, and both received DELTON (J\&J) pit and fissure sealant. The samples were examinated by scanning electron microscopy (SEM), which showed that the patterns obtained by the phosphoric acid etching were uniform presenting a great quantity of microporosities thus being considered superior to the pattern obtained by the Nd: YAG laser etching, either by $1.00 \mathrm{w}$ or $0.75 \mathrm{w}$. The formation of tags showed better results in the group treated by the phosphoric scid than in that treated with $\mathrm{Nd}$ : YAG laser.
\end{abstract}

(J. Jpn. Soc. Laser Dent. 5:59 65, 1994 Reprint requests to Dr. Carlos P. EDUARDO)

Key words: etching, Nd: YAG laser, phosphoric acid, tags, tooth enamel, SEM.

\section{Introduction}

The increased retention of the restorative acrylic materials following enamel acid etching was first developed by Buonocore ${ }^{11}$. Since then, many surveys have been performed in order to improve new materials, restorative techniques and the enamel etching, including the use of laser.

The development of the laser use is being fast in mary fields of Dentistry; one of them is the tooth enamel etching technique. Thus, Goodman $\& \mathrm{Gwinnett}^{2)}$ used the argon laser. Kumazaki ${ }^{3)}$, Gross et al. ${ }^{4}$ and Wright et al. ${ }^{5)}$ used the Er: YAG laser; Lippas et al ${ }^{6}{ }^{6}$ used differents kinds of laser ( $\mathrm{Ho}$ : YAG ; $\mathrm{CO}_{2} ; \mathrm{CO}_{2} / \mathrm{Nd}$ : YAG and $\mathrm{Ar}: \mathrm{F}$ ).

Hess $^{7)}$ studied morphologic changes of the tooth enamel using the Nd: YAG laser and suggested that this method was simple, effective and controlled due to the changes of the enamel characteristics.

Myers \& Riddle ${ }^{8)}$ used extracted human teeth to compare the morphologic changes of the enamel etching by phosphoric acid and the Nd: YAG laser. They found similar results, considering depth penetration and morphologic changes.

Abed et al. ${ }^{9)}$ compared the adhesion power of

* Departamento De Ortodontia E Odentopediatria Faculdade De Odontologia Da Universidade De Sao Paulo.

Av. Prof. Lineu Prestes-2227 CEP. 05508-900-Cidade Universitaria-Sao Paulo, Brazil. 
orthodontics brackets to the $37 \%$ acid-etched tooth enamel and the $\mathrm{Nd}$ : YAG laser $(75 \mathrm{~mJ}$ and 15pps). They mentioned that the adhesion was greater with acid than with laser etching but there was no grea differences between the two methods analysed.

The purpose of this investigations was to compare the effects of the Nd: YAG laser on enamel surface and the Kumazaki's ${ }^{3)}$ technique, as well as the formation of tags using the scanning electron microscopy.

\section{Materials and Methods}

Ten sound permanent canine teeth, extracted upon clinical indication and stored in saline solution, were used.

The teeth were cleaned with pumice and water, using a bristle brush mounted in a conventional dental handpiece, air dried and randomly divided into in five groups (two teeth for each group).

In groups 1 and 4 , the teeth were submitted to enamel acid etching technique in the middle third of the vestibular face, with $35 \%$ phosphoric acid in gel for 30 seconds and rinsed for 20 seconds.

In two acid etched teeth (Group 4) the DELTON $(J \& J)$ pit and fissure sealant was applied according to the manufacture's instructions. After polymerization, the teeth were treated by a $10 \%$ nitric acid solution for 5 to 7 days in order to obtain the samples.

In groups 2, 3 and 5, the teeth were etched with the Nd: YAG laser with a "d Lase-300" machine (AMERICAN DENTAL LASER COMPANY). The area to be etched (in the third of the vestibular face), was set with wato proof black ink. The laser was applied on two teeth (Group 2) for 90 seconds, power $1.00 \mathrm{w}$ and 15 pulses per second.

In groups 3 and 5 , we used four teeth (two in each). The power level was $0.75 \mathrm{w}$ and $15 \mathrm{pps}$ for 90 seconds, as described by Abed et al. ${ }^{8)}$

In the teeth of group 5 it was also applied the DELTON (J\&J) pit and fissure sealant, according to the manufacturer's instructions. After polymerization, the teeth were treated with $10 \%$ nitric acid solution, during 5 to 7 days to obtain the sample.

\section{Results}

In samples from the group 1(acid etched) it was observed a great amount of microporosities referring to the type I pattern reported by Silverstone et al. ${ }^{10)}$ (Figs. 1 and 2).

In Group $2(1.00 \mathrm{w})$, the surface presented numerous microporosities quite differents to those observed in Group 1 (Figs. 3 and 4).

In Group $3(0.75 \mathrm{w})$, it was observed a greater number of microporosities than that observed in Group 2 (Fig. 5).

In Group $1\left(\mathrm{H}_{3} \mathrm{PO}_{4}\right)$, no cracks were observed in the enamel (Fig. 1), while such structures were present in Group $2(1.00 \mathrm{w})$ and $3(0.75 \mathrm{w})$ (Figs. 1 and 5).

Concering the microporosities, depth it may be seen that they are apparently bigger and more uniform in Group 1 $\left(\mathrm{H}_{3} \mathrm{PO}_{4}\right)$, than in Group 2 $(1.00 \mathrm{w})$ and $3(0.75 \mathrm{w})$, where they were apparantly smaller and irregular.

The diameter of the microporosities, was apparently uniform in Group $1\left(\mathrm{H}_{3} \mathrm{PO}_{4}\right)$, while in Group $2(1.00 \mathrm{w})$ and $3(0.75 \mathrm{w})$ there was quite a variation.

The surfaces of the enamel treated by the $\mathrm{Nd}$ : YAG laser showed vitrification areas.

In Group 4 (acid + pit and fissure sealant), the formation of tags was more uniform and numerous than in Group 5 (Laser + pit and fissure sealant), (Figs. 6 and 7).

\section{Discussion}

Since the first work of Buonocore ${ }^{1)}$ to increase the retention area on the enamel surface, there has been a greater development of the techniques and materials to restore and seal pit and fissures. From this proposed concept, many techniques for retention to the tooth surface are being studied, among them is the laser enamel etching.

$\mathrm{Hess}^{7)}$ studied the effects of the Nd: YAG laser on the tooth enamel and found that there was a total lack of cracks. In our results we found cracks in Groups 2 and 3 (Figs. 4 and 5), and in greater number in Group 2, probably due to either the energy level released by the laser $(1.00 \mathrm{w}$ against $0.75 \mathrm{w}$ in group 3 ) or dryness for SEM preparation. 
Also, our findings revealed the presence of vitrified areas which are similar to those reported by $\mathrm{Hess}^{6)}$.

Althoug Myers \& Riddle ${ }^{8)}$ described that both the acid and the laser energy penetrates the enamel in aproximately the same depth, our results showed that the acid etching penetrated deeper than the laser.

We found a greater number of microporosities, which are deeper and more uniform in Group 1 $\left(\mathrm{H}_{3} \mathrm{PO}_{4}\right)$ than in group 2 and 3 (respectively $1.00 \mathrm{w}$ and $0.75 \mathrm{w})$. So, it might be concluded that the adhesion power was bigger in Group $1\left(\mathrm{H}_{3} \mathrm{PO}_{4}\right)$.

Such hypothesis is more evident when we noticed that the tags formed by the acid etching on the enamel (Group 4), are broader and more uniform than the areas examined in Group $5(0.75 \mathrm{w})$.

In Lippas et al. ${ }^{6)}$ observations, the acid etched samples showed a different pattern from the laser etched ones. Such evidence confirms our results, in which we observed that Group $3(0.75 \mathrm{w})$ shows a slightly greater number of microporosities than the Group 2(1.00w). In spite of this, the size of the microporosities varried in a similar pattern for both groups.

On the other hand, our data revealed that the uniformity of the size of tags in Group $4\left(\mathrm{H}_{3} \mathrm{PO}_{4}\right.$ + pit and fissure sealant), differing from those obtained in Group 5 (laser+pit and fissure sealant), probably due to the presence of perikymates, areas of hipomineralization of the enamel which form irregular surfaces difficulting the use of $\mathrm{Nd}$ : YAG laser.

It is important to emphasize that our results were obtained for teeth under radiation for 90 seconds and power level $0.75 \mathrm{w}$ and $1.00 \mathrm{w}$, with 15 pps, therefore further studies should be carried out to find out the ideal time for the laser application and the amount of energy transferred to the tooth tissue.

\section{Conclusions}

Acording to the our results we conclude the followings :

The etching pattern for the enamel surface us- ing $35 \%$ phosphoric acid for 30 seconds, was the most effective ;

The Nd: YAG laser etched surface by $0.75 \mathrm{w}$ (Groups 3), showed a slightly greater number of microporosities when compared to the $1.00 \mathrm{w}$ (Group 2) ;

Cracks on the surfaces treated by the laser, and in greater number in group 2 were observed; and There were tags in a more uniform way in Group $4\left(\mathrm{H}_{3} \mathrm{PO}_{4}+\right.$ pit and fissure sealant $)$, than in Group 5 (laser + pit and fissure sealant).

\section{References}

1) Buonocore, M. G.: A simple method of increasing the adhesion of acrylic filling materials to enamel surfaces. J Dent Res, 34 : 849 - 853, 1955.

2) Goodman, B. D., Gwinnett, A. J.: A comparison of laser-etched human enamel using scanning electron microscopy. Arch Oral Biol. 22 : 15 - 20, 1977.

3) Kumazaki, M.: Results of etching with the Er: YAG laser. In: Third international congress on lasers in dentistry. Salt Lake City, Aug. 6-8. Proccedings. Salt Lake City, 1992. p. 22.

4) Gross, D., Raab, W. H. M., Keller, U., Hibst, R.: Surface morphology of dental hard tissues after Er: YAG laser treatment. In: Third international congress on lasers in dentistry. Salt Lake City, Aug. 6-8. Proccedings. Salt Lake City, 1992. p. 20.

5) Wright, G. A., McConnell, R. J., Kelle, U.: Microleakage around resin restorations prepared with an $\mathrm{Er}$ : YAG laser, In: Third international congress on lasers in dentistry. Salt Lake City, Aug. 6-8. Proccedings. Salt Lake City, 1992. p. 11.

6) Lippas, M. G., Arcoria, C. J., Khademi, J. A.: Surface analysis of $\mathrm{Ho}$ : YAG, $\mathrm{CO}_{2}, \mathrm{CO}_{2} / \mathrm{Nd}$ : YAG \& Ar: $\mathrm{F}$ laser. In: Third international congress on lasers in de ntistry. Salt Lake City, Aug. 6-8. Proccedings. Salt Lake City, 1992. p. 21.

7) Hess, J. A. : Scanning electron microscopy study of laserreduced morphologic changes of a coated enamel surface. Lasers Surg. Med., 10 : 458-462, 1990.

8) Myers, T. D., Riddle, J. M.: Comparative morphological effects of enamel etching with phosphoric acid and a pulsed Nd: YAG laser. In: Second international society of laser dentistry. world congress. Paris, May 28-31, 1990.

9) Abed, S., Hess, J., Shivapla, A.: Bond strength of orthodontic brackets to acid-etched and laser-etched enamel. In: International academy of laser dentistry. Boston, Oct 13, 1990. Abstract.

10) Sliverstone, L. M., Saxton, C.A., Dogon, I. L., Fejerskov, O.: Variation in the pattern of acid etching human dental enamel examined by scanning electron microscopy, Caries Res, 9 : 373-387, 1975. 
Fig. 1 Scannnig electron micrography showing a general view of enamel acid etching surface. $\times 1,250$.

SEM finding of acid etched enamel with $35 \%$ phophoric acid. A great amount of microporosities were observed.

Fig. 2 In high magnification, showing the type 1 pattern (Silverstone et $\mathrm{al}^{10)}$ ). $\times 3,750$. Larger magnification of Fig. 1.

Fig. 3 Scanning electron micrography showing an enamel surface containning numerous microporsities. $\times 375$.

SEM finding of etched enamel with $1.0 \mathrm{w}$ of laser.

Fig. 4 In high magnification, showing the vitrificated areas $\left(^{*}\right)$, and samall holes (arrows). $\times 4,500$.

Larger magnification of Fig. 3.

Fig. 5 Scanning electron micrography showing numerous microporosities of different sizes. $\times 1,250$.

Microporosities of enamel with quite a variation was observed after $0.75 \mathrm{w}$ laser etching.

Fig. 6 Scanning electron micrography showing the distribution of tags. $\times 850$.

More uniform and numerous tag formation was observed after treating with phosphoric acid etching plus pit \& fissure sealant.

Fig. 7 Scanning electron micrography showing the groups of tags (arrows) and fissures $\left({ }^{*}\right) . \times 850$.

Less uniform and number of tag was observed after treating with laser etching plus pit \& fissure sealant. 


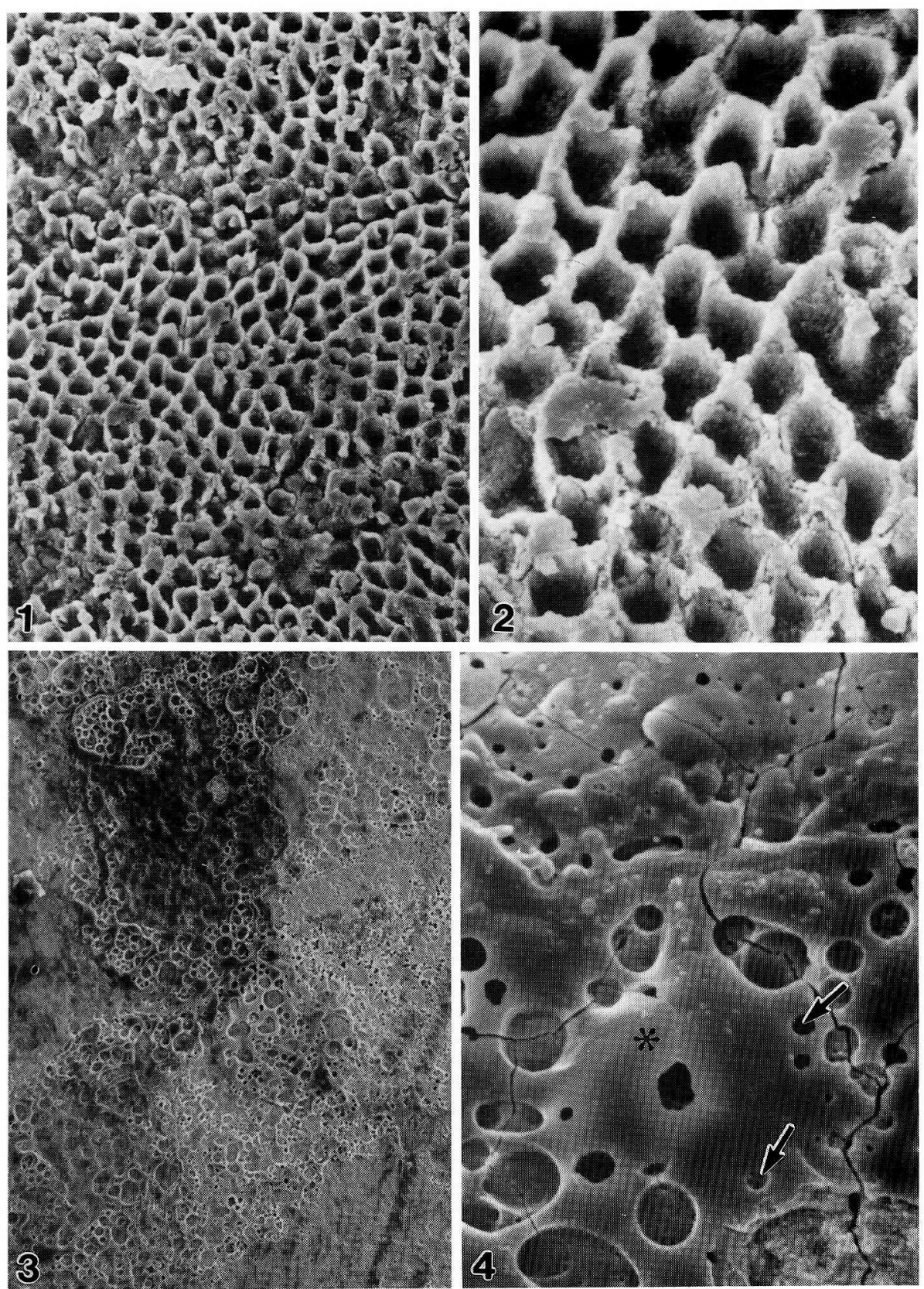




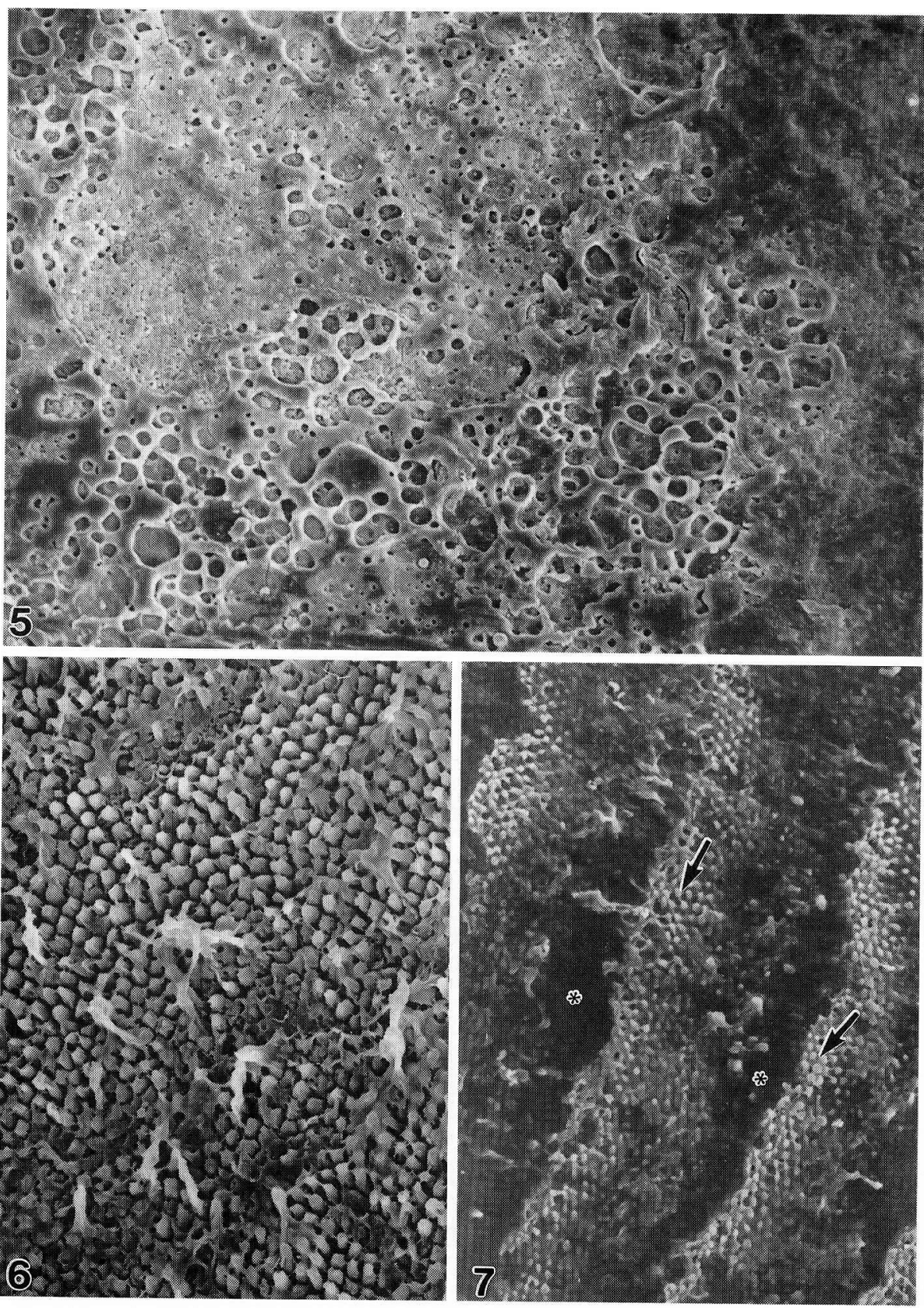




\section{Nd-YAG レーザー並びに燐酸でエッチングした エナメル質表面の性状比較 \\ シリービオ I. ミヤキ他 \\ サンパウロ大学歯学部並びにサンパウロ大学バイオメディカル科学研究所 \\ (受理 : 平成 6 年 1 月 31 日)}

要旨：ヒトのエナメル質を $35 \%$ リン酸および $\mathrm{Nd}: \mathrm{YAG} レ$ レ゙ー $(0.75 \mathrm{~W} \sim 1.00 \mathrm{~W}, 15 \mathrm{pps}, 90$ 秒 $)$ 照射 の 2 つ異なる方法でエッチングしエナィル質の表面性状を比較検討した。

エッチングされたエナメル質表面に両群共, 窩溝填塞剤である Delton（J\&J）を填塞し tag 形成の状態 を2 群で比較した。その結果, Nd：YAG レーザーでエッチングしたエナィル質の場合より，リン酸でェッ チングしたエナメル質に多量の microporosities（脱灰された小柱端末）がユニフォームに形成された。ま た tag 形成についても，Nd：YAGレーザーで処置したエナメル質よりリン酸で処置したエナメル質にお いて良好であることが示された。

キーワードニエッチング、 Nd：YAG レーザー, 燐酸、タグ、エナメル質, SEM 